\title{
A Study on Equity and Distribution of National Income and Poverty Method
}

\author{
Lucas Bottcher \\ GISMA Business School, Berlin, Germany \\ bottcher@gmail.com
}

Article Info

Journal of Journal of Enterprise and Business Intelligence (http://anapub.co.ke/journals/jebi/jebi.html)

Doi: https://doi.org/10.53759/5181/JEBI202101023

Received 30 April 2021; Revised form 28 July 2021; Accepted 25 August 2021.

Available online 05 October 2021.

(C2021 Published by AnaPub Publications.

\begin{abstract}
The study offers an analysis of two important indicators: the equity of the distribution of national income and poverty, using the Gini coefficient, as it gives a numerical measure of the equity of the distribution. The last decades in Iraq and Egypt have witnessed widening the gap between different income groups due to several economic, political, and social factors. Therefore, the research focused on analyzing and measuring the phenomenon of poverty and its relation to the equity of income distribution for a sample of developing countries based on the annual statistical bulletins of the World Bank. Research has increased the phenomenon of poverty. In Iraq, based on national income per capita and total household consumption data using the Gini coefficient, the research concluded with a set of conclusions. The most important is the widening of the gap between per capita consumption and total family consumption increase in national income in Iraq. About the analysis of the phenomenon of Poverty in Egypt, the great disparity is also evident. In the poverty gap between national income per capita and total household consumption, despite the increase in national income in both countries, indicating low national income equity in both countries, and this is the result of the high cost of living and low real incomes, as well as the depreciation of the local currency. Therefore, the research problem boils down to whether the increase in the national income rate reflects positively in reducing inequality in the income distribution of the two countries and reduces the phenomenon of poverty.
\end{abstract}

Keywords- Distribution of National Income; Poverty; Phenomenon of Poverty; Capita Consumption; Gini Coefficient; Economy Suffer; Local Currency.

\section{INTRODUCTION}

The economic literature indicates the many attempts made by economists and statisticians to measure income inequality. They refer to Pareto's law, which states that the level of inequality increases with increasing income. National, due to the emergence of forces affecting the fairness of the distribution of national income, the first of which is corruption. This leads to a decrease in the number of beneficiaries. More precisely, the distribution of national income is inversely proportional to the individuals who own it. Rather than any real distribution of income, it mediates between the state of equality and its gap. We, therefore, use the Gini coefficient and the Lorenz curve to indicate the extent of income inequality [1].

The question of income and the fairness of its distribution is one of the questions which arouse interest not only in the economic fields but in the social, political and other fields because of the high degree of inequality in the distribution of economic life, especially those at the bottom of the social structure, which leads to real problems. Interest in income distribution has grown, especially since the 1960s, when several experiments in developing countries revealed that disparities in income distribution become more acute in the early stages of economic development [2]. That is why he started with the main interest in social and economic plans in most countries globally, including Iraq and Egypt, to achieve greater equity in distributing income among members. To develop policies and plans that would redistribute income to benefit low-income population groups that suffer from declining absolute and relative income levels [3]. On the other hand, tackling inequality requires the adoption of economic policies and programs to reduce poverty levels, requiring the availability of special indicators [4]. To achieve this goal, this study focuses on measuring and analyzing the disparity in income distribution and Poverty in Iraq and Egypt, using the Gini coefficient. 


\section{THEORETICAL FRAMEWORK}

Several studies have analyzed poverty and poor fairness in the distribution of national income, given the importance of analyzing that phenomenon and its reflection on society. A study prepared by [5] and the researcher Muhammad Hassan Odeh analyzed welfare and its relationship to average and fair national income. It concluded that there are economic and social distortions in the Iraqi economy, which prompted the government to adopt a policy of support and intervention, which carried a great burden on the public budget to achieve and reach the economic well-being of citizens [6]. The investment spending must be given greater importance because this leads to an expansion of productive capacities, increased production and economic growth, leading to an increase and permanence of economic welfare in Iraqi society. At the same time, a study prepared by the ESCWA team of the United Nations examined the analysis of poverty in developing countries. The study classified societies below the poverty line and those who obtain daily incomes of less than one dollar per day and has classified the levels of the phenomenon of poverty into several types, including extreme Poverty and moderate Poverty [7].

First: analyze measures of private income and expenditure in Iraq

Per capita income is one of the most indicative measures of the standard of living and well-being of society, and in the Table below, the per capita share of national income in Iraq, as follows: According to the per capita income index, Iraq tops the list of countries considered in terms of the poverty level. However, Iraq is one of the countries that have conducted individual expenditure surveys since 1946 [8]. Nevertheless, the successive political and security situations thwarted any economic development. Plans that have adopted poverty eradication strategies and the poor distribution of national income among groups of people, while the Ministry of Labor and Social Affairs and its social welfare institutions have sought to reduce poverty rates, did not succeed. On the contrary, the poverty rate has increased, pushing nearly 4 million people into poverty, according to statistics. The United Nations Department of Humanitarian Affairs, while the Central Bureau of Statistics of the Ministry of Planning and Development Cooperation conducted a survey which showed that more than 9 million Iraqis are below the poverty line, the poverty rate has exceeded 23\% of the total population [9]. The government adopted Central is a poverty reduction program after 2003, through the development of two strategies, the first strategy (2010-2014), which focused on analyzing the internal and external factors behind poverty, while the second strategy addressed (2018-2022) The four main challenges are security and stability, good governance, equitable distribution of national income and diversification of sources of national income, and the fourth is to reduce the negative effects of economic reform [10]. It is possible to identify certain variables of the Iraqi economy to analyze the phenomenon of poverty. Using the following tables:

Table 1. Economic variables of Iraq (Values are in current US dollar prices)

\begin{tabular}{|c|c|c|c|}
\hline Years & $\begin{array}{c}\text { per capita } \\
\text { national income }\end{array}$ & $\begin{array}{c}\text { Private sector expenditures } \\
\text { (Billion\$) }\end{array}$ & $\begin{array}{c}\text { Gross National Income } \\
\text { (Billion\$) }\end{array}$ \\
\hline 2004 & - & 13.443 & 36.68 \\
\hline 2005 & - & 18.745 & 45.427 \\
\hline 2006 & 1.9 & 24.21 & 61.594 \\
\hline 2007 & 2.43 & 34.245 & 85.773 \\
\hline 2008 & 3.54 & 41.146 & 135.098 \\
\hline 2009 & 4.16 & 58.338 & 114.755 \\
\hline 2010 & 4.58 & 61.56 & 140.054 \\
\hline 2011 & 4.96 & 66.164 & 185.233 \\
\hline 2012 & 6.3 & 86.608 & 218.866 \\
\hline 2013 & 7.04 & 113.804 & 233.587 \\
\hline 2014 & 6.83 & 121.547 & 233.344 \\
\hline 2015 & 5.93 & 103.325 & 175.982 \\
\hline 2016 & 5.62 & 112.134 & 173.335 \\
\hline 2017 & 4.88 & 114.882 & 194.029 \\
\hline 2018 & 5.06 & 128.945 & 222.472 \\
\hline 2019 & 5.74 & 146.807 & 232.981 \\
\hline
\end{tabular}

From the data in Table 1, it becomes clear that the per capita income is meagre, since it reached about 1900 dollars per year in 2004, or about 3.8 million Iraqi dinars, to rise to about 7 thousand dollars in 2014 to be paid. To 5.7 thousand dollars in 2019, or about 7 million Iraqi dinars per year, and therefore with a drop in per capita income, it is the first cause of the increase in Poverty in Iraq despite the high values of the national income during the period 
under discussion, which we will discuss later. Relative to the other countries in the sample in terms of per capita share, we find that Iraq is the lowest level of livelihood, and this is the result of the reasons that the World Bank referred to in determining the criteria affecting the input share of countries, including economic growth, inflation, exchange rates and population growth, and these factors have been affected in their entirety after 2003, in particular, the number of the population which has experienced a significant boom and a weak economic development in Iraq it therefore directly affects the per capita income [11].

Regarding the total expenditure of the private sector, we note that it has taken an upward trajectory, with the expansion and opening of the economy and the liberation to the outside world and the feeling of poverty experienced by the Iraqi individual in the country. The 1990s following the imposition of international sanctions, which was reflected in high levels of private spending. (1) We note that the total final private sector expenditure amounted to $\$$ 13.443 billion in 2004 , rising to $\$ 61.56$ billion in 2010, then increased significantly in 2019 to reach $\$ 146.807$ billion. US dollars, which indicates the effect of goods and services on domestic demand; besides the increase in population, the Iraqi population reached 26.340 million in 2003, bringing the population to about 33.330 million people in 2011 [12]. Then it will grow to nearly 40 million people in 2019.

Considering the values of national income in Iraq presented in Table (1), we note that it has an upward trajectory due to the increase in oil income after allowing Iraq to re-export oil after 2003. Successive governments have sought to find alternatives to diversify sources of national income. However, rapid changes in security and politics have made the Iraqi economy suffer from continuous crises [13]. It is vulnerable to fluctuations in the global oil market instead of investing the huge money and savings in oil revenues that Iraq obtained between 2008 and 2013. However, the issue was reflected in the high operating expenses only. It did not resolve the Structural Imbalances of the Economy in Iraq, including improving levels of societal well-being; the opposite is accompanied by high returns, increased Poverty and low rates of poverty. Homage. US dollars in 2011, then to 233 billion US dollars in 2019, as the following graph shows in figure 1.

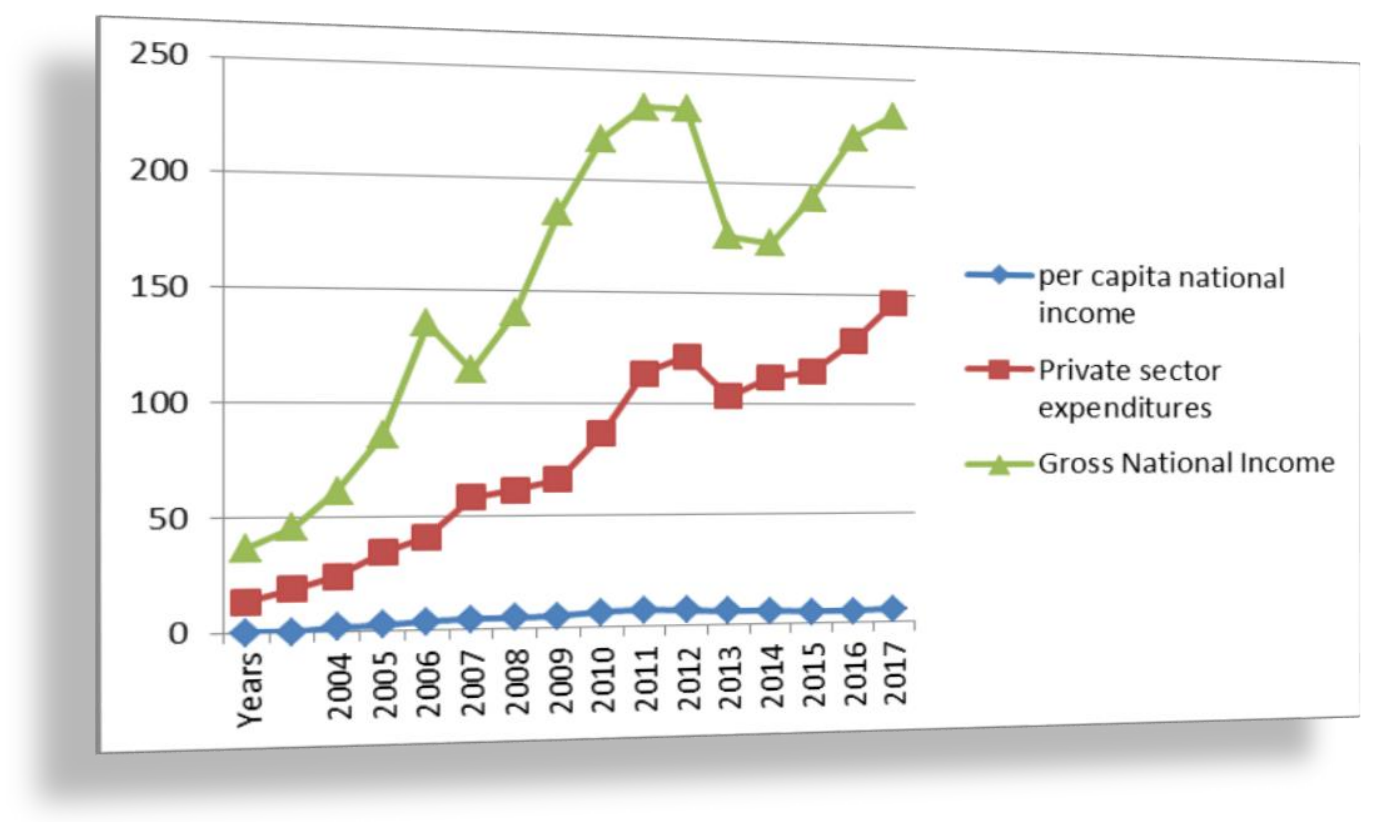

Fig 1. The development of indicators of the Iraqi economy

Figure based on table (1) data Second: Analysis of the measurement of national income and private expenditure of the Egyptian Arab Republic [14]. Since 2005, the Egyptian government has sought to develop strategies to get rid of the problem of poverty by tracking the cost of basic needs, as the poverty line is determined according to the costs of the needs of Egyptian families for necessary food and not - basket while following the spending habits of households below the poverty line, and the two most important characteristics of the estimated poverty and poor distribution of national income, the first is to calculate the poverty line according to the age and sex composition of each family, while the other factor is the frequent updating of the poverty food basket as it is updated periodically between (20102011) and (2012-2013), L The initial survey carried out by the team preparing this report indicates that the poverty rate has fallen from 24.3. \% between 2010-2011 to 21.4\% in 2012-2013. It had about 50.6\% of the poor in Egypt in 2005, and it still contained more than $40 \%$ of the poor in 2010. The cities of Lower Egypt had the lowest percentage 
of low-income families in 2010 because they contained less than $5 \%$ of the poor and $12 \%$ of the population [15]. An introduction to some of the variables related to the distribution of national income and private sector expenditure, we will analyze the data in the following Table 2:

Table 2. Economic variables of the Arab Republic of Egypt) Values are in current US dollar prices

\begin{tabular}{|c|c|c|c|}
\hline Years & $\begin{array}{c}\text { per capita } \\
\text { national } \\
\text { income }\end{array}$ & $\begin{array}{c}\text { Private sector expenditures } \\
\text { (Billion \$) }\end{array}$ & $\begin{array}{c}\text { Gross National Income(Billion } \\
\$ \text { ) }\end{array}$ \\
\hline 2004 & 6.630 & 56.461 & 78.575 \\
\hline 2005 & 7.010 & 64.109 & 89.346 \\
\hline 2006 & 7.640 & 75.843 & 107.956 \\
\hline 2007 & 8.290 & 94.43 & 131.614 \\
\hline 2008 & 8.890 & 117.745 & 164.177 \\
\hline 2009 & 9.140 & 143.938 & 189.300 \\
\hline 2010 & 9.330 & 163.303 & 214.618 \\
\hline 2011 & 9.440 & 178.33 & 229.940 \\
\hline 2012 & 10.840 & 225.283 & 272.637 \\
\hline 2013 & 10.930 & 232.976 & 281.027 \\
\hline 2014 & 10.640 & 253.457 & 298.332 \\
\hline 2015 & 11.310 & 271.495 & 323.665 \\
\hline 2016 & 11.040 & 276.22 & 327.970 \\
\hline 2017 & 10.800 & 207.737 & 231.165 \\
\hline 2018 & 11.350 & 213.37 & 243.433 \\
\hline 2019 & 10.460 & 251.395 & 253.221 \\
\hline
\end{tabular}

From the data in Table (2), we notice that the average per capita share of gross national income increased from $\$$ $6,630,000$ per year to $\$ 9,330,000$ in 2010 . In subsequent years, the per capita fluctuation rose to 11,310 in 2015 . It dropped to 10,460 USD in 2019 [15]. It has taken an upward trajectory about private sector spending, indicating an increase in demand for the basket of basic needs. They reached $\$ 56.461$ billion in 2004, rising to $\$ 163.303$ in 2010 , then private spending continued to increase to $\$ 251.395$ billion in 2019 .

This indicates an increase in demand for cash balances. Regarding the gross national income, the Egyptian government has experienced a great economic expansion in the field of manufacturing and agriculture, as the percentage of the contribution of these two sectors to the formation of the gross domestic product has increased, as well as the tourism sector, in addition to the extraction and mining sector. From the data in Table (2), we note that the total income. The national has taken an upward trajectory, reaching 78.575 billion dollars in 2004, rising to 229.940 billion dollars in 2010, to continue to rise to 253.221 billion dollars. US dollars in 2019, and the figure 2 below shows the data values in Table 2.

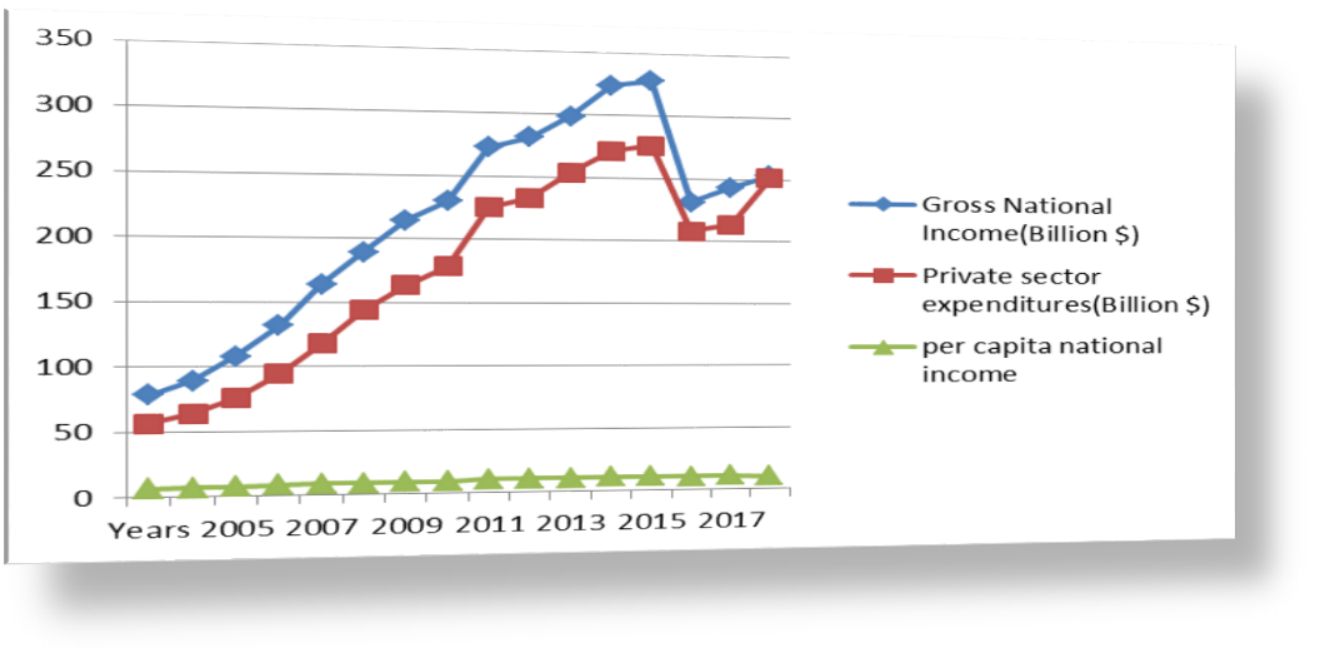

Fig 2. The development of the Egyptian economy indicators 
From the above, the Egyptian government depends on its investments from the Ministry of Defense for most of the investment joints. Despite increasing the population to nearly 100 million people, it has implemented two plans to stimulus for the Egyptian economy by allocating 3\% of the gross domestic product in 2014, with a focus on capital spending, which includes the establishment of planned megaprojects that involve economic and financial risks, but which also include strong increases in public sector wages and pensions, which help most middle incomes. With further structural reforms to put the public budget and debt levels on a sustainable path and stimulate strong economic growth led by the private sector. It is accompanied by exchange rate flexibility [16]. It is an important factor in promoting macroeconomic stability, intensive growth in labour utilization and export competitiveness [17].

The second requirement: the analysis of the Gini poverty coefficient

Analysis of the poverty gap in Iraq

In this requirement, the poverty gap was analyzed using the Gini coefficient for total national income per capita in Iraq and Egypt, and according to the Lorenz curve as shown in the figures below, because the higher the difference between this curve and the line of symmetry, the higher the poverty rate and vice versa.

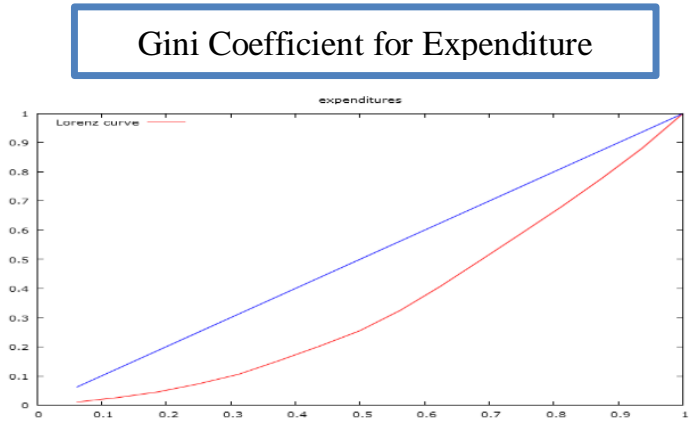

Sample Gini coefficient $=0.308477$

Estimate of population value $=0.329042$

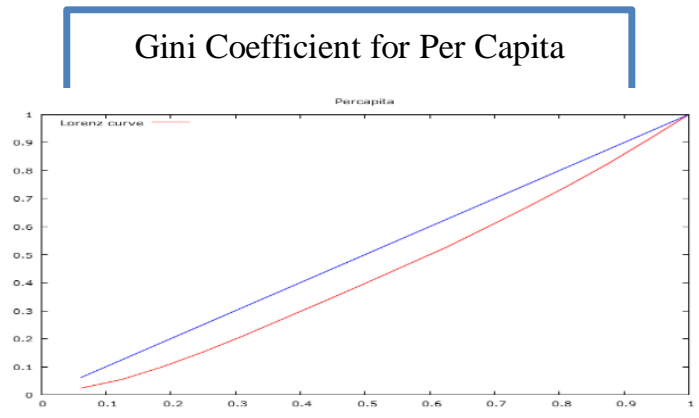

Sample Gini coefficient $=0.152795$

Estimate of population value $=0.162982$

Fig 3. Analysis of the poverty gap in Iraq

The figure 3 was prepared by researchers based on the data in Table (2) and using the Gretl statistical program .It is evident from the above analysis from the charts that there is a gap between income per capita and total private-sector consumption expenditure.

Analysis of poverty gaps in the Arab Republic of Egypt

After analyzing the poverty gap in Iraq, we will analyze the gap in Egypt based on per capita income and total family expenditure statistics, and according to the following analysis results:

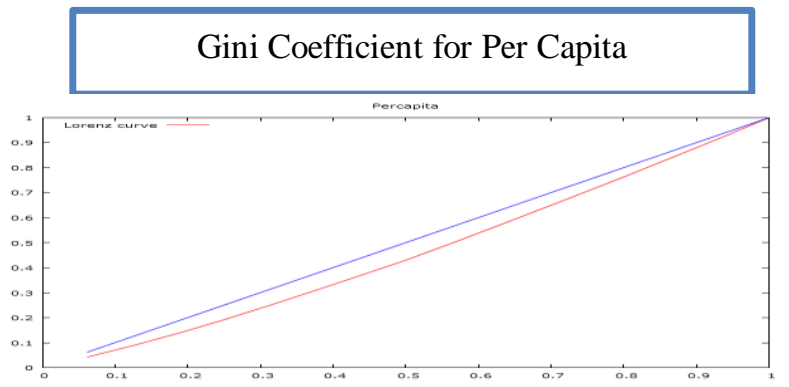

Sample Gini coefficient $=0.0912584$

Estimate of population value $=0.0973423$

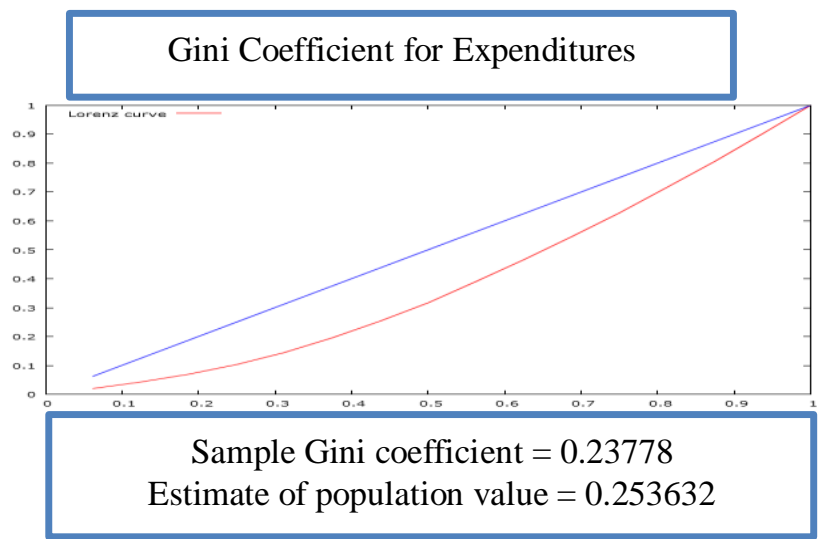

Fig 4. Analysis of poverty gaps in the Arab Republic of Egypt 
The figure 4 was prepared by researchers based on the data in Table (2) and using the Gretl statistical program. The results were different from the analysis of the poverty gap in Iraq, as the disparity in the Republic of Egypt favoured total family consumption, as can be seen from the figures above the widening of the gap between consumption per capita and total consumption. Therefore, the gap in family consumption increases with the increase in national income, which indicates the rise in living standards. The fall in the Egyptian public's purchasing power is the fall in real income, even with the increase in per capita income.

The third requirement: the quantitative model

In this proposal, we will try to build a standard model to measure the effect of the variables (national income and total family consumption in per capita terms in Iraq and the Arab Republic of Egypt for the period (2004-2019), depending on what follows: Description of the standard models: In preparation for the evaluation of the standard models, we will define the variables included in the model for Iraq and Egypt as follows in table 3:

Table 3. Characterization of model variants

\begin{tabular}{|c|c|c|c|c|c|}
\hline \multicolumn{3}{|c|}{ مصر - مصر } & \multicolumn{3}{|c|}{ العراق } \\
\hline 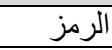 & الحالة & 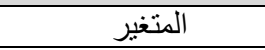 & 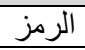 & الحالة & 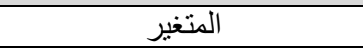 \\
\hline Neg & تابع & $\begin{array}{l}\text { The share of the } \\
\text { Egyptian income }\end{array}$ & Nirq & تابع & The share of Iraqi income \\
\hline Ineg & تق & $\begin{array}{l}\text { Egyptian national } \\
\text { income }\end{array}$ & Inirq & ت & Iraqi national income \\
\hline Peg & صשית & $\begin{array}{l}\text { Total family } \\
\text { consumption }\end{array}$ & Pirq & صنس & $\begin{array}{l}\text { Total family } \\
\text { consumption }\end{array}$ \\
\hline
\end{tabular}

Unit root test

Regression analysis depends on the stability of time series values to avoid false regression, so data from tables (1) and (2) were entered to ensure no unit root, meaning that the time series does not suffer trend. Accordingly, the following test results were reached:

Table 4. Augmented Dickey-Fuller test

\begin{tabular}{|c|c|c|c|c|c|c|c|c|c|c|c|}
\hline \multicolumn{6}{|c|}{ Augmented Dickey-Fuller test for Egypt } & \multicolumn{6}{|c|}{ Augmented Dickey-Fuller test for Iraq } \\
\hline \multirow{2}{*}{ Prob } & \multicolumn{3}{|c|}{ Critical value } & \multirow{2}{*}{$\begin{array}{l}\text { estimated } \\
\text { value }\end{array}$} & \multirow{2}{*}{ Variables } & \multirow{2}{*}{ Prob } & \multicolumn{3}{|c|}{ Critical value } & \multirow{2}{*}{$\begin{array}{l}\text { estimated } \\
\text { value }\end{array}$} & \multirow{2}{*}{ Variables } \\
\hline & $10 \%$ & $5 \%$ & $1 \%$ & & & & $\% 1$ & $\% 5$ & $\% 10$ & & \\
\hline 0.019 & $\begin{array}{c}- \\
3.388\end{array}$ & $\begin{array}{c}- \\
3.875\end{array}$ & 4.992 & -4.574 & $N$ & 019 & $2 . \overline{7} 54$ & $\begin{array}{c}- \\
1.970\end{array}$ & $\begin{array}{c}- \\
1.603 \\
\end{array}$ & -2 & $\mathrm{Nl}$ \\
\hline 0.009 & 1.603 & 1.970 & 2.754 & & & 00 & $4 . \overline{0}$ & 3.119 & $2 . \overline{701}$ & . & Q \\
\hline 0.011 & $\begin{array}{c}- \\
2.701\end{array}$ & $\begin{array}{c}- \\
3.119\end{array}$ & $\begin{array}{c}- \\
4.057\end{array}$ & -3.969 & PEG & 0.017 & $\begin{array}{c}- \\
2.754\end{array}$ & $\begin{array}{c}- \\
1.970\end{array}$ & $\begin{array}{c}- \\
1.603\end{array}$ & -2.490 & PIRQ \\
\hline
\end{tabular}

Source: Prepared by the researcher based on the results of Interviews

From the results of Table 4 and after the introduction of the variables in Iraq considered, we did not reach the stability of the time series for the variables; the analysis was therefore reworked after taking the first difference so that the series has stabilized at a significance level of $5 \%$ for the per capita variable and $1 \%$ for the national income variable. In comparison, the series for family consumption set at the significance level is $5 \%$ since the calculated t-value of the variables is less than its critical value. Therefore, the null hypothesis indicates the existence of the unit root. Therefore, the validity of the variables to enter the regression analysis was rejected. Concerning the variables of the Egyptian economy considered, it is clear from the results of the Table above that the variables did not stabilize at the level, the calculated value of $(t)$ exceeding its tabular equivalent, the test therefore been repeated after taking the first difference to stabilize them all at the 5\% level, so we accept the alternative hypothesis and reject the null hypothesis, indicating that there is no root.

\section{Estimation Of The Linear Regression Function}

At this point, the variable regression function of the Iraqi economy has been estimated for the manifestations of the impact of national income and total household consumption on per capita income, estimating the effect of both national income gross and household expenditure on per capita income in Iraq, so that we can achieve the following results: 


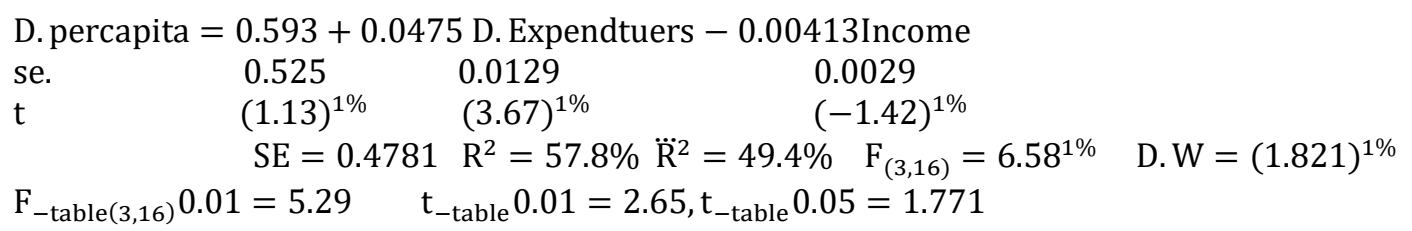

The positive relationship between total household consumption and national income per capita is evident through the above results. In contrast, a negative relationship between income per capita and gross national income has emerged. However, it is about a low impact relationship according to the R2 statistic, which indicates an explanation of 58\% of the total changes due to internal variables. For the model, $48 \%$ is due to other external variables. Considering the rest of the test, it passed the test. The calculated tabular F value exceeded the significance level of $1 \%$. The test Dw indicated that the model was capable of autocorrelation between random residuals, thus reconciling the significance of the estimated model. As for the results of the estimation of the regression function of the variables of the Egyptian economy, they can be drawn from the following analysis results:

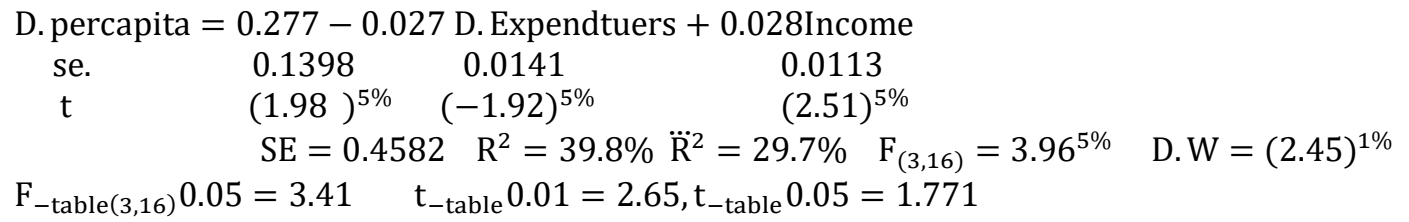

The above analysis results show the negative relationship between family consumption and national income per capita and corroborate the results of the Gini coefficient analysis, as there is a gap between family consumption and the per capita share. Simultaneously, the analysis showed a direct relationship between national and per capita income of $0.02 \%$, a weak relationship. Given the importance of the estimated model, the calculated t-test value exceeded its tabular counterpart at the 5\% significance level. The F-test indicated the significance of the estimated model because its value exceeded the critical value of the 5\% significance level. The Dw test also showed that the model was devoid of autocorrelation among the random residuals.

\section{CONCLUSIONS}

Although Iraqi per capita income has taken an upward trajectory, it remains at a low level compared to neighbouring countries and developed countries, and this is the result of the structural problems plaguing the Iraqi economy and the impact economic variables over them, including declining real incomes, rising exchange rates and increasing population growth, and these factors were affected in their entirety after 2003, especially the population, which achieved a solid boom and weak economic development in Iraq, thus directly affecting per capita income. With the adoption by the Egyptian government of a stimulus policy to push investments in the main sectors, industry, agriculture and the extractive sector, but this was not reflected in the improvement in gross national income per capita, as the results of statistical analysis showed the small effect of the increase in national income. It is also the result of many problems The Egyptian economy has suffered, especially the fall in the pound's exchange rate against the US dollar, the rise in the consumer price index, and the fall in real income. With the increase in total family consumption in Iraq and Egypt, this was not reflected in the achievement of public welfare, conclusion 1,2 during the period under discussion since most of the expenses are spent on basic goods such as food and drink and spending on housing, services, and health care. According to the Gini coefficient, the increase in poverty in the two countries was reflected even with the increase in national income in the two countries. The disparity in the distribution of income in Egypt is less than in Iraq, despite the strong demographic growth in Egypt, which has almost reached 100 million. The results of the quantitative analysis showed the weak effect of increasing both national income and total family consumption.

\section{References}

[1]. S. Jain, S. S. Jain, and G. V. Jain, "Intelligent Transportation System Based Traffic Congestion Modeling for Urban Corridor," Civil Engineering and Urban Planning: An International Journal (CiVEJ), vol. 4, no. 2, pp. 37-48, Jun. 2017.

[2]. F. Agyapong and T. K. Ojo, "Managing traffic congestion in the Accra Central Market, Ghana," Journal of Urban Management, vol. 7, no. 2, pp. 85-96, Sep. 2018.

[3]. R. Arnott and E. Inci, "An integrated model of downtown parking and traffic congestion," Journal of Urban Economics, vol. 60, no. 3, pp. 418-442, Nov. 2006.

[4]. D. J. Graham, "Variable returns to agglomeration and the effect of road traffic congestion," Journal of Urban Economics, vol. 62, no. 1, pp. 103-120, Jul. 2007. 
[5]. J. Kanyepe, M. Tukuta, and I. Chirisa, "Urban Land-use and Traffic Congestion: Mapping the Interaction,” Journal of Contemporary Urban Affairs, vol. 5, no. 1, pp. 77-84, Jan. 2021.

[6]. L. Wen, J. Kenworthy, X. Guo, and D. Marinova, "Solving Traffic Congestion through Street Renaissance: A Perspective from Den se Asian Cities," Urban Science, vol. 3, no. 1, p. 18, Jan. 2019

[7]. F. Agyapong and T. K. Ojo, "Managing traffic congestion in the Accra Central Market, Ghana," Journal of Urban Management, vol. 7, no. 2, pp. 85-96, Sep. 2018.

[8]. Y. Hou, "Traffic Congestion, Polycentricity, And Intraurban Firm Location Choices: A Nested Logit Model For The Los Angeles Metropolitan Area," Journal of Regional Science, vol. 56, no. 4, pp. 683-716, May 2016.

[9]. G. Prokop, "Modeling Human Vehicle Driving by Model Predictive Online Optimization," Vehicle System Dynamics, vol. 35, no. 1, pp. 19-53, Jan. 2001

[10]. M. Gutierrez Soto and H. Adeli, "Many-objective control optimization of high-rise building structures using replicator dynamics and neural dynamics model," Structural and Multidisciplinary Optimization, vol. 56, no. 6, pp. 1521-1537, Oct. 2017.

[11]. H. Yoshioka, "A simplified stochastic optimization model for logistic dynamics with control-dependent carrying capacity," Journal of Biological Dynamics, vol. 13, no. 1, pp. 148-176, Jan. 2019.

[12]. Z. Heszberger and J. Bíró, “An optimization neural network model with time-dependent and lossy dynamics," Neurocomputing, vol. 48, no. 1-4, pp. 53-62, Oct. 2002.

[13]. P. XIONG, "Business performance prediction and optimization model based on system dynamics," Chinese Journal of Mechanical Engineering, vol. 44, no. 04, p. 107, 2008.

[14]. L. Sen and X. H. Ma, "Molecular Dynamics Optimization of a Computational Model of TACE and its Substrate Peptide," Advanced Materials Research, vol. 680, pp. 131-136, Apr. 2013.

[15]. Y. Zhou, "DNA Epidemic Model Construction and Dynamics Optimization," International Journal of Cognitive Informatics and Natural Intelligence, vol. 14, no. 3, pp. 97-117, Jul. 2020.

[16]. E. J. Ferreyra, M. Jonckheere, and J. P. Pinasco, "SIR Dynamics with Vaccination in a Large Configuration Model," Applied Mathematics \& Optimization, Jul. 2021.

[17]. G. N. Absi and S. Mahadevan, "Simulation and Sensor Optimization for Multifidelity Dynamics Model Calibration," AIAA Journal, vol. 58, no. 2, pp. 879-888, Feb. 2020. 